\title{
Effect of Water Status on Dendrobium Flower Spray Postharvest Life
}

\author{
Jingwei Dai' and Robert E. Pau11 ${ }^{2}$ \\ Hawaii Institute of Tropical Agriculture and Human Resources, University of Hawaii at Manoa, \\ 3190 Maile Way, Honolulu, HI 96822 \\ Additional index words. floral preservative, chilling injury, antimicrobial agents, water stress, flower handling
}

Abstract. The postharvest life of Dendrobium spp. flower sprays was limited by wilting and shedding of individual 'flowers. Late-summer-harvested sprays had a reduced postharvest life compared to winter-harvested sprays. Cultivars differed in postharvest life in response to packing and storing for 2 days at $22 \mathrm{C}$. Water 10ss rates of 'Princess' sprays continuously held in deionized water declined from $\approx 1.25 \mathrm{~g} / \mathrm{day}$ per spray 4 days after harvest to $0.35 \mathrm{~g} / \mathrm{day}$ per spray 20 days later. Flower shedding occurred when the rate of water loss fell below $\approx 1.0$ g/day per spray. Addition of a floral preservative to the vase water slowed the decline in water loss and increased postharvest life. Sprays packed and stored for 6 days at $22 \mathrm{C}$ had half the postharvest life of nonpacked controls held in deionized water or of sprays packed for 2 or 4 days at 22C. Submerging sprays in water immediately after harvest did not significantly increase postharvest life; submerging the sprays after harvest, before packing, and again after unpacking reduced postharvest life. Sprays could not be held for more than 4 days at $10 \mathrm{C}$ without suffering chilling injury. Silver thiosulphate (2 mM) and other silver preparations had no effect on postharvest life, although silver ions did reach the top flowers of the spray; thus, ethylene may play only a minor role in spray postharvest life. The postharvest life of sprays was increased by using boiled deionized water in vase solutions and by the continuous presence of chloramphenicol. Other antimicrobial agents, such as Physan, sodium hypochlorite, and sodium dichloro-s-triazinetrione dihydrate were without effect. Microbial growth in the vase solution and at the cut stem end mav have reduced water transport and induced subsequent flower wilting and shedding.

Dendrobiums are a major ornamental crop in Hawaii. The flowers are used locally as cut flower sprays and in making flower leis (Kamemoto, 1987). Cut flower sprays are also exported to the mainland United States and Canada. Dendrobium sprays bear from five to 30 flowers on an unbranched raceme, and buds open acropetally along the stalk (Nair and Tung, 1983; Sheehan, 1983). The flowers last from 8 to 30 days (Nair and Fong, 1987; Nolte, 1985), depending on cultivar (Kamemoto, 1987) and flower age at harvest (Nair and Tung, 1983).

Dendrobium flowers have a low sensitivity to ethylene (Gob et al., 1985) when compared to the extreme sensitivity of Vanda (Akamine, 1963; Burg and Dijkman, 1967) and Phalaenopsis (Huang et al., 1988) orchids. Ethylene is produced during dendrobium senescence (Nair arid Fong, 1987; Nair and Tung, 1983), although its role is unclear.

Some research has shown that silver nitrate added as an antimicrobial agent did not markedly improve postharvest life of some orchids (Nowak and Vacharotayan, 1980), possibly due to poor silver distribution. However, other workers demonstrated that silver nitrate, when continuously present in the holding solution, did increase postharvest life of dendrobium flowers (Ketsa and Boonrote, 1990), probably by acting as an antimicrobial agent.

Microbial growth in the vase solution and related vascular plugging has been suggested to be the cause of reduced postharvest life in Oncidium orchids (Yong and Ong, 1979). Microbial contamination played a role in vascular blockage and

Received for publication 23 May 1990. Hawaii Institute of Tropical Agriculture and Human Resources Journal Series no. 3462. We express appreciation for the technical assistance provided by Gail Hamada and Wendy Kimura. Mention of a trademark or proprietary product does not constitute a guarantee or warranty of a product by the Univ. of Hawaii, and does not imply its approval to the exclusion of other products that may also be suitable. The cost of publishing this paper was defrayed in part by the payment of page charges. Under postal regulations, this paper therefore must be hereby marked advertisement solely to indicate this fact.

'Graduate Student, Dept. of Horticulture.

${ }^{2}$ Plant Physiologist, Dept. of Plant Molecular Physiology. was a major factor limiting postharvest life in other flower species (Mayak et al., 1977; Put and Jansen, 1989; van Doom et al., 1989; Witte and van Doom, 1988; Zagory and Reid, 1986). The major microorganisms associated with reduced postharvest life of cut carnation, rose, and chrysanthemum were a yeast and a fluorescent and a nonfluorescent pseudomonas (Zagory and Reid, 1986). Microbial growth in vase solutions was found to be affected by 8-hydroxyquinoline (Larson and Cromarty, 1967); however, 8-hydroxyquinoline may have physiological effects on the flowers (Marousky, 1971). Ketsa and Boonrote (1990) found that 8-hydroxyquinoline increased the postharvest life of dendrobium flowers.

Complaints about the short postharvest life of dendrobiums have been received by exporters in Hawaii. The problems experienced included unacceptable variability in postharvest life and premature flower shedding. This research was directed at determining which factors affecting dendrobium spray postharvest life could be controlled in commercial production and handling practices.

\section{Materials and Methods}

Plant material. Dendrobium flowers were obtained from a commercial grower on the island of Oahu. The cultivar Supreme was used unless otherwise stated. Flowers were harvested in the late morning with three to six unopened flower buds, with open flowers comprising two-thirds to three-fourths of the total flowers. Flowers were submerged in tap water for 6 to $10 \mathrm{~min}$ immediately after harvest and returned to the laboratory within 3 $h$ of harvest with their stems in water. Two centimeters of stem was removed before treatment began. Those sprays showing petal or stem damage were discarded.

Flower quality was evaluated every other day. The vase life was defined as ended when $50 \%$ of the raceme's individual flowers present at harvest had wilted and fallen off. Ten to 12 flower sprays were used in each treatment and were evaluated individually.

Simulated shipping. Sprays were either immediately packed 
with moistened shredded newspaper in commercial flower boxes lined with polyethylene film or held in solutions overnight before being packed. During the period in boxes, the cut flower stems were held with deionized water or other chemical solutions absorbed on cotton and then were wrapped in a small plastic bag. Some flowers were submerged in tap water immediately before packing and after unpacking. The boxes were held for 2 days at $22 \mathrm{C}$ or as otherwise indicated. The flowers were then unpacked, after which $2 \mathrm{~cm}$ of flower stem was removed. Flowers were placed in a l-liter conical flask containing deionized water or other chemical solutions and held for evaluation at $22 \mathrm{C}$, with $70 \%$ to $80 \%$ relative humidity $(\mathrm{RH})$, four air changes per hour, and a 10- to 12-h combination of normal sunlight plus fluorescent light $\left(46 \mu \mathrm{mol} \cdot \mathrm{s}^{-1} \cdot \mathrm{m}^{-2}\right)$.

Water loss. A flower spray was placed in a test tube containing deionized water or Oasis Floral Preservative (Smithern-Oasis, Kent, Ohio) solution $(2 \% \mathrm{w} / \mathrm{v})$. The test tube was covered with a piece of parafilm to prevent water evaporation. At the start of the experiment and at various intervals, the weight of the test tube with the spray was determined. The difference between consecutive weighings was used to calculate water loss rates.

Chilling injury. Sprays were held at 1, 5, 7.5, or 10C with Oasis Floral Preservative $(2 \% \mathrm{w} / \mathrm{v})$ in the vase for various lengths of time, then returned to $22 \mathrm{C}$. The respective $\mathrm{RH}$ was $\approx 70 \%$, $80 \%, 65 \%$, and $65 \%$. Sprays were monitored daily for chillinginjury (CI) symptoms.

Silver analysis. Sprays were treated with $2 \mathrm{~mm} \mathrm{Ag}\left(\mathrm{S}_{2} \mathrm{O}_{3}\right)_{2}$ for 4 or $8 \mathrm{~h}$ immediately upon return to the laboratory, then placed into deionized water for 20 and $16 \mathrm{~h}$, respectively. Flowers on the sprays were then separated into the upper, middle, and lower third of the spray. Stems were similarly sectioned. Silver ion concentrations were determined using $10 \mathrm{~g}$ of flowers and $5 \mathrm{~g}$ of stem tissue digested with concentrated nitric acid at 100C, and analyzed by atomic absorption spectroscopy.

Statistical analysis. All experiments were repeated at least twice, treatment results were cross-checked with similar treatments in other experiments. Where possible, mean comparisons were made using analysis of variance and the Wailer-Duncan multiple range test (SAS Institute, Inc., Cary, N.C.).

\section{Results}

Water loss from cut dendrobium sprays. Water loss by sprays held continuously in deionized water after harvest remained constant at $\approx 1.25 \mathrm{~g} /$ day per spray for $\approx 7$ days, then declined to $0.4 \mathrm{~g} /$ day per spray 20 days after harvest (Fig. 1). Sprays packed and held for 2 days immediately after harvest had a higher rate of water loss during the first 4 days after harvest [1.4 and 1.9 g/day per spray in water and Oasis Floral Preservative (2\% w/ v) vase solutions, respectively] than nonpacked sprays. The packed sprays had significantly higher rates of water loss by 14 days after harvest than those not packed. Flower sprays continuously held in Oasis Floral Preservative had a higher rate of water loss by 16 days after harvest than sprays held in deionized water. Flower shedding began when water loss dropped to $\approx 1.0 \mathrm{~g} /$ day per spray in all treatments, 9 to 17 days after harvest.

Seasonal and plant age variation. The average vase life during the cooler February to June period (Fig. 2A) was 20 days for the control and 34 days for sprays held in Oasis Floral Preservative (2\% w/v) (Fig. 2B). During the warmer August to November period, the average vase life was $\approx 12$ days for the deionized water control and $\approx 18$ days in Oasis Floral Preservative, $30 \%$ and $35 \%$, respectively, less than during spring. Post-

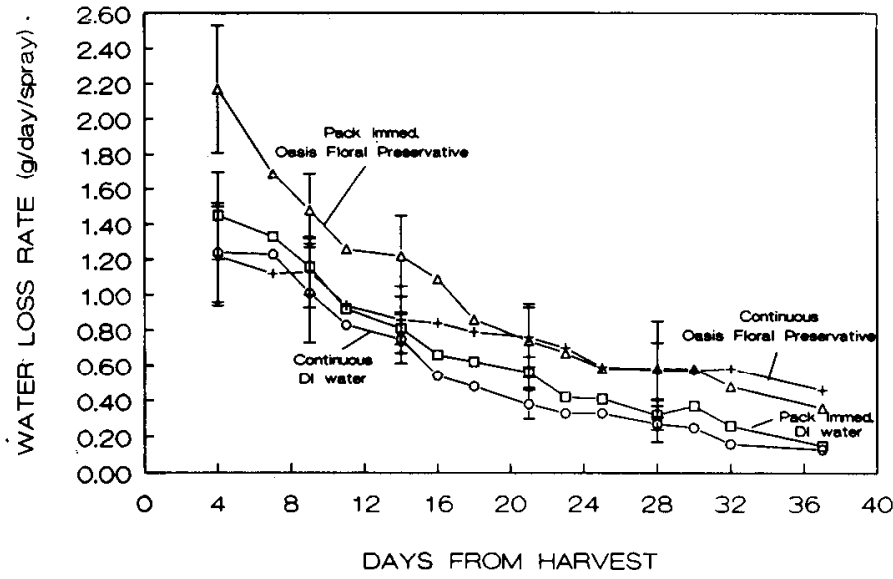

Fig. 1. Water 10ss from dendrobium sprays held in deionized water $(0-0)$ or Oasis Floral Preservative $(2 \%$ w/v) continuously $(+-+)$ or packed immediately and held for 2 days at 22C. The spray's stem was immediately recut after unpacking and returned to either deionized water $(\square-\square)$ or Oasis Floral Preservative $(\Delta-\Delta)$. Vertical lines represent SD of mean, $n=8$.
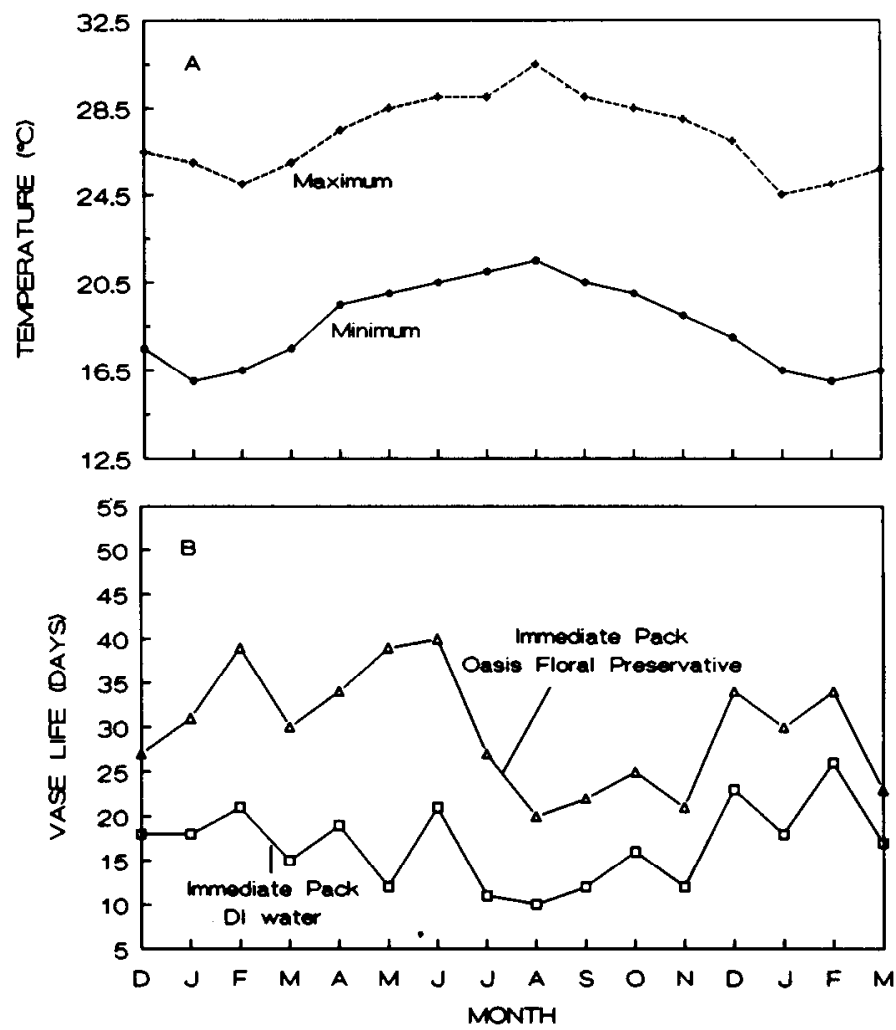

Fig. 2. Monthly variation in average minimum and maximum air temperature (A) and dendrobium spray postharvest life (B). Sprays were immediately packed and held for 2 days at 22C. After unpacking, $2 \mathrm{~cm}$ of stem was cut off and sprays were placed in either deionized water $(\square-\square)$ or Oasis Floral Preservative $(2 \%$ w/v) $(\Delta-\Delta)$. Analysis of variance: month $* * *$, treatment $* *$, month $\times$ treatment **. Significant at $P \geq 0.05(*), 0.01(* *)$, or $0.001(* * *)$.

harvest vase life increased again in November. Sprays from plants varying in age from 24 to 45 months did not have significantly different postharvest lives when held in deionized water or in Oasis Floral Preservative (data not shown).

Cultivar differences. Holding packed sprays for 2 days after harvest, then placing them into deionized water significantly 
decreased the vase life of all cultivars, except 'Princess' (Table 1). Treatment with Oasis Floral Preservative following 2 days of being packed increased the vase life of cultivars by $144 \%$ to $225 \%$ (difference significant at $P=0.01$ ) compared to flowers held in deionized water after unpacking (data not shown). The degree of response to the preservative depended on the cultivar and on the time of packing, with 'Pearl' being more responsive $(225 \%)$ than 'Supreme' (144\%) or 'Prince' (154\%) when flowers were packed immediately after harvest. When packing was delayed $24 \mathrm{~h}$, the response to the preservative was increased to $166 \%$ for 'Supreme' and $171 \%$ for 'Prince' due to the comparative decline in the postharvest life of control sprays held in deionized water.

Postharvest handling. Submerging sprays at harvest, before packing, 'and again after unpacking significantly reduced (19\%) postharvest vase life relative to all other treatments (Table 2). These flowers showed no disease symptoms, although petals frequently showed translucence, possibly due to water-soaking of tissue. Submerging sprays in water for 5 to $10 \mathrm{~min}$ only before packing or only after packing did not significantly affect postharvest vase life. No significant difference in postharvest life was found between stems recut in air or under 20C or 60C water immediately after unpacking (data not shown).

None of the prepacking treatments significantly increased postharvest life above the packed deionized water control (Table 3). Floralife (Smithers-Oasis, Kent, Ohio), Rogor Sustaining Solution (GARD Products, Arlington Heights, 111.), and sucrose used before packing decreased postharvest life compared to the

Table 1. Postharvest life of Dendrobium cultivars held continuously in deionized water or of sprays held packed for 2 days with stems immediately recut after unpacking, then placed in deionized water.

\begin{tabular}{lccc}
\hline \hline & & \multicolumn{2}{c}{ Postharvest life (days) } \\
\cline { 3 - 4 } & & \multicolumn{2}{c}{ Deionized water } \\
\cline { 3 - 4 } Cultivar & Hawiv. of & Continuously & $\begin{array}{c}\text { After sprays held } \\
\text { packed 2 days }\end{array}$ \\
\hline Supreme & 232 & $23 \mathrm{a}^{\mathrm{z}}$ & $19 \mathrm{~b}$ \\
Pearl & 306 & $20 \mathrm{ab}$ & $13 \mathrm{~cd}$ \\
Prince & 503 & $19 \mathrm{~b}$ & $16 \mathrm{c}$ \\
Blush & 44 & $16 \mathrm{c}$ & $13 \mathrm{~d}$ \\
Princess & 507 & $19 \mathrm{~b}$ & $19 \mathrm{~b}$ \\
Analysis of variance & & $*$ & \\
Cultivar (CV) & & & $* *$ \\
Packing (PK) & & & $* *$ \\
CV $\times$ PK & & &
\end{tabular}

${ }^{\mathrm{z}}$ Mean separation by Duncan-Waller multiple range test $(P<0.01)$, $\mathrm{n}=10$. Analysis of variance significant at $P=0.01$.

Table 2. Effect of submerging dendrobium sprays in deionized water for $5 \mathrm{~min}$ at harvest, immediately before packing, or after being held packed for 2 days with stems in deionized water absorbed on cotton. All stems were immediately recut after unpacking and placed in deionized water.

\begin{tabular}{cccc}
\hline \hline & Submerged & \multicolumn{2}{c}{ Postharvest life } \\
\hline At harvest & Before packing & After packing & $(\mathrm{days})_{2}$ \\
\hline- & - & - & $21 \mathrm{ab}$ \\
- & - & + & $20 \mathrm{~b}$ \\
- & + & - & $22 \mathrm{a}$ \\
+ & - & - & $20 \mathrm{~b}$ \\
+ & + & + & $17 \mathrm{c}$ \\
\hline
\end{tabular}

${ }^{ }$Mean separation by Duncan-Wailer multiple range test $(P<0.01)$, $\mathrm{n}=10$.
Table 3. Effect of prepacking solutions on postharvest life of dendrobium sprays held in various solutions overnight before packing and holding for 2 days. Stems were immediately recut after unpacking. Sprays were then returned to the same solution or deionized water.

\begin{tabular}{|c|c|c|}
\hline \multicolumn{2}{|c|}{ Solution } & \multirow{2}{*}{$\begin{array}{l}\text { Postharvest life } \\
\text { (days) }^{z}\end{array}$} \\
\hline Prepacking & Postpacking & \\
\hline
\end{tabular}

\begin{tabular}{lll} 
Prepacking & Postpacking & (days) \\
\hline Deionized water &
\end{tabular}

continuously (no packing) 19 de

OFPy continuously

(no packing)

Deionized water

OFP $(2 \% \mathrm{w} / \mathrm{v})$

Floralife $(2 \% \mathrm{w} / \mathrm{v})$

Silflor-50, 2 h $\left(2 \mathrm{ml} \cdot\right.$ liter $\left.^{-1}\right)$

Silflor-50, 2 h ( 20 ml-liter $\left.{ }^{-1}\right)$

Rogor Sustaining Solution

$\left(10 \mathrm{ml} \cdot\right.$ liter $\left.^{-1}\right)$

Chrysal SVG-II, 2 h

Chrysal $(1 \% \mathrm{w} / \mathrm{v})$

Silgard $\left(16 \mu \mathrm{l} \cdot\right.$ liter $\left.^{-1}\right)$

$\mathrm{AgS}_{2} \mathrm{O}_{3}, 2 \mathrm{~h}(4 \mathrm{mM})$

Sucrose, 24 h (5\% w/v)

32 a

$32 \mathrm{a}$
$23 \mathrm{~b}$

20 cde

OFP

Floralife

$18 \mathrm{e}$

Deionized water $22 \mathrm{bc}$

OFP $(2 \% \mathrm{w} / \mathrm{v}) \quad 19 \mathrm{de}$

${ }^{2}$ Mean separation by Duncan-Wailer multiple range test $(P<0.01)$, $\mathrm{n}=10$.

${ }^{y} \mathrm{OFP}=$ Oasis Floral Preservative.

deionized water packed control. Completely covering the flowers with plastic in the $24 \mathrm{~h}$ before holding them packed for 2 days did not increase postharvest life (data not shown).

Holding sprays overnight at $10 \mathrm{C}$ in deionized water before packing increased postharvest life from 16 to 19 days (significant at $P=0.01$ ). Mild symptoms of $\mathrm{CI}$, i.e., black spots on the lip, slight water-soaking of petals, and failure of buds to open, occurred with more than 4 days exposure to 10C. At $7.5 \mathrm{C}, 2$ to 4 days of exposure was sufficient to develop CI. Sprays held at 1 or $5 \mathrm{C}$ developed CI, i.e., petal and bud discoloration, drying, and flower shedding, after 1 day.

Sprays whose stems were held in deionized water or in Oasis Floral Preservative absorbed on cotton in a small plastic bag attached to the cut stems, packed immediately, and held for 2 and 4 days at $22 \mathrm{C}$ did not have reduced postharvest life after unpacking (Table 4). Being packed for 6 days reduced postharvest vase life by $\approx 56 \%$ for sprays held in deionized water when compared to sprays immediately packed and held for 2 days. The reduction in postharvest life when preservative solutions were used was $\approx 68 \%$ of that of sprays not packed. Holding flowers in deionized water for $24 \mathrm{~h}$ before holding them packed for 6 days gave a decline in postharvest life similar to packing them immediately. Sprays held in deionized water for $48 \mathrm{~h}$ before being packed and held packed for more than 2 days had one-third the postharvest life after unpacking as the nonpacked controls (data not shown). Having the stem ends in absorbent cotton with water or Oasis Floral Preservative during holding in packages did not significantly affect spray postharvest life (data not shown).

Effect of preservative solutions. Holding flowers continuously in chloramphenicol $\left(1 \mu \mathrm{g} \cdot \mathrm{ml}^{-1}\right)$ increased postharvest vase life by $50 \%$ relative to the control (Table 5 ). The use of boiled water or Oasis Floral Preservative $(3 \% \mathrm{w} / \mathrm{v})$ increased postharvest life by $30 \%$ and $92 \%$, respectively. No improvement in postharvest life was observed with other materials tested (Table 5).

The commercial preservative Oasis Floral Preservative dou- 
Table 4. Effect of duration of packed storage on postharvest life of sprays immediately packed or held in solution overnight, then held packed for 2,4, or 6 days with deionized water or Oasis Floral Preservative $(2 \% \mathrm{w} / \mathrm{v})$ absorbed on cotton. Stems were immediately recut after unpacking and returned to the same solution.

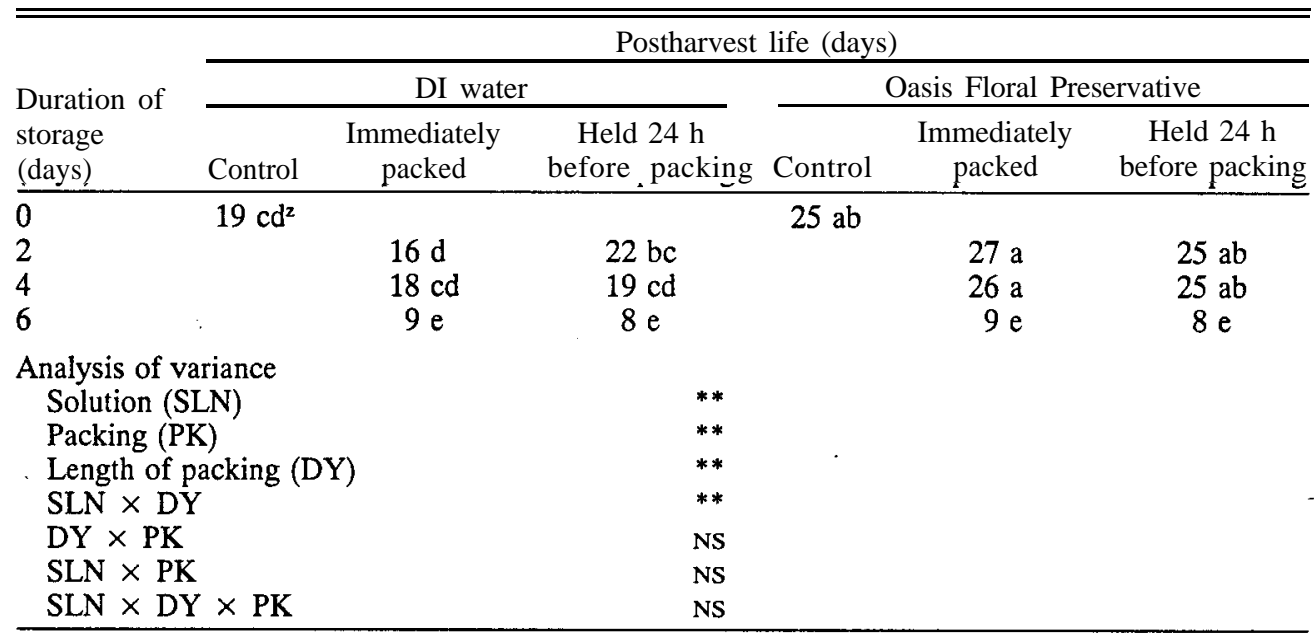

${ }^{2}$ Mean separation by Duncan-Wailer multiple range test $(P<0.01), \mathrm{n}=12$. Analysis of variance significant at $P=0.01$.

Table 5. Effect of various antimicrobial agents on postharvest life of dendrobium sprays. Flowers were held overnight in respective solutions, held packed for 2 days, unpacked, stems immediately recut after unpacking, and placed in deionized water.

\begin{tabular}{|c|c|}
\hline Prepacking solution & $\begin{array}{c}\text { Postharvest life' } \\
\text { (davs) }\end{array}$ \\
\hline Control & $12 \mathrm{~d}$ \\
\hline Filtered water $(0.45 \mu \mathrm{m})$ & $13 \mathrm{~d}$ \\
\hline Boiled water & $16 \mathrm{c}$ \\
\hline Sodium hypochlorite $\left(4 \mu \mathrm{l} \cdot\right.$ liter $\left.^{-1}\right)$ & $13 \mathrm{~d}$ \\
\hline Chloramphenicol $\left(10 \mathrm{mg} \cdot\right.$ liter $\left.^{-1}\right)$ & $18 \mathrm{~b}$ \\
\hline Thiabendazole ( $\left.300 \mathrm{mg} \cdot \mathrm{liter}^{-1}\right)$ & $12 \mathrm{~d}$ \\
\hline Physan-20 $\left(200 \mu \mathrm{l} \cdot\right.$ liter $\left.^{-1}\right)$ & $12 \mathrm{~d}$ \\
\hline Oasis Floral Preservative ( $3 \% \mathrm{w} / \mathrm{v})$ & $23 \mathrm{a}$ \\
\hline \multicolumn{2}{|l|}{ Sodium dichloro-s-triazinetrione } \\
\hline dihydrate $\left(150 \mathrm{mg} \cdot\right.$ liter $\left.^{-1}\right)$ & $13 \mathrm{~d}$ \\
\hline \multicolumn{2}{|l|}{ Sodium dichloro-s-triazinetrione } \\
\hline dihydrate $\left(750 \mathrm{mg} \cdot\right.$ liter $\left.^{-1}\right)$ & $13 \mathrm{~cd}$ \\
\hline
\end{tabular}

${ }^{2} \overline{\text { Mean }}$ separation by Duncan-W̄Walier multiple range test $(P<0.01)$, $\mathrm{n}=12$.

bled postharvest vase life relative to the control when used preand postpacking (Table 6). The optimum concentration for the preservative was found to be $\approx 2 \%(\mathrm{w} / \mathrm{v})$ (data not shown), with concentrations up to $4 \%(\mathrm{w} / \mathrm{v})$ showing no additional increase in postharvest life. Rogor Sustaining Solution (10 ml-liter $\left.{ }^{-1}\right)$, used before packing, slightly improved postharvest life, while no improvements were observed with the range of other commercial preservatives tested (Table 6).

Distribution of silver in sprays. A higher content of silver in flowers and stem sections from the bottom than from the top part of the spray was observed after $4 \mathrm{~h}$ (Table 7). Silver, however, did reach the top flowers of the sprays. The content of silver in the top stem section and top flowers was $57 \%$ and $43 \%$, respectively, of that in the bottom sections after $4 \mathrm{~h}$ in 2 mm silver thiosulfate. Longer exposure $(8 \mathrm{~h})$ approximately doubled the silver content in all flowers and stem sections, except the bottom stem section.
Table 6. Effect of preservative solutions on postharvest life of dendrobium sprays. Flowers held overnight in various prepacking solutions and then held packed for 2 days. Stems were immediately recut after unpacking and the spray placed in the postpacking solution.

\begin{tabular}{|c|c|c|}
\hline \multicolumn{2}{|c|}{ Solution } & \multirow{2}{*}{$\begin{array}{c}\text { Postharvest life } \\
\text { (days) }\end{array}$} \\
\hline Prepacking & Postpacking & \\
\hline Deionized water & Deionized water & $10 \mathrm{bcd}$ \\
\hline OFPy $(3 \% \mathrm{w} / \mathrm{v})$ & OFP & $20 \mathrm{a}$ \\
\hline Floralife $(2 \% \mathrm{w} / \mathrm{v})$ & Floralife & $10 \mathrm{~cd}$ \\
\hline Silflor- $50,2 \mathrm{~h}$ & Water & $8 \mathrm{~d}$ \\
\hline Silflor- $50,2 \mathrm{~h}$ & Floralife $(3 \% \mathrm{w} / \mathrm{v})$ & $9 d$ \\
\hline Silgard $\left(16 \mathrm{ml} \cdot\right.$ liter $\left.^{-1}\right)$ & Water & $9 \mathrm{~cd}$ \\
\hline \multicolumn{3}{|l|}{ Rogor Sustaining Solution } \\
\hline$\left(10 \mathrm{ml} \cdot\right.$ liter $\left.^{-1}\right)$ & Water & $13 \mathrm{~b}$ \\
\hline Chrysal $(1.5 \% \mathrm{w} / \mathrm{v})$ & Chrysal & $8 \mathrm{~d}$ \\
\hline Decor $(1.5 \% \mathrm{w} / \mathrm{v})$ & Decor & $9 \mathrm{~cd}$ \\
\hline
\end{tabular}

${ }^{z}$ Mean separation by Duncan-Waller multiple range test $(P<0.01)$, $\mathrm{n}=10$.

y OFP = Oasis Floral Preservative.

\section{Discussion}

Preharvest factors, such as cultivar differences (Table 1) and seasonal variation (Fig. 2B), contributed to the variability in postharvest life of dendrobium sprays. There was an overall reduced vase life in the period from late summer to late fall. Pool et al. (1984) showed that high growing temperatures for leatherleaf fern produced fronds with a relatively short vase life, which was associated with the lowered water uptake ability of cut leatherleaf fronds (Stamps et al., 1989). A negative correlation was found between leatherleaf fern frond growth rate and vase life. A similar situation may exist with dendrobium in that the longest postharvest life occurred when the spray load on each plant was lowest. The physiological causes are unclear, although differences in resistance to water flow through the stem may be a possibility.

Cultivar differences in vase life were observed, with 'Supreme' generally having the longest postharvest life. Cultivar 
Table 7. Distribution of silver ions in dendrobium sprays treated for 4 or $8 \mathrm{~h}$ with $2 \mathrm{~mm}$ silver thiosulfate, then placed in deionized water for an additional 20 or $16 \mathrm{~h}$, respectively, before silver analysis.

\begin{tabular}{|c|c|c|c|c|c|c|}
\hline \multirow{3}{*}{$\begin{array}{l}\text { Duration of } \\
\text { STS pulsing } \\
\text { (h) }\end{array}$} & \multicolumn{6}{|c|}{ Silver content (ng $\cdot \mathrm{g}^{-1}$ fresh wt) } \\
\hline & \multicolumn{3}{|c|}{ Flowers } & \multicolumn{3}{|c|}{ Stem } \\
\hline & Top & Middle & Bottom & Top & Middle & Bottom \\
\hline$\overline{0}$ & 0 & 0 & 0 & 0 & 0 & 0 \\
\hline 4 & 0.03 & 0.06 & 0.07 & 0.12 & 0.20 & 0.21 \\
\hline 8 & 0.07 & 0.14 & 0.18 & 0.23 & 0.38 & 0.29 \\
\hline \multicolumn{7}{|l|}{ Analysis of variance } \\
\hline Stem position & \multicolumn{2}{|c|}{$* * *$} & \multicolumn{4}{|c|}{$* * *$} \\
\hline Silver treatment & \multicolumn{2}{|c|}{$* * *$} & \multicolumn{4}{|c|}{$* * *$} \\
\hline Position $\times$ silver & \multicolumn{2}{|c|}{$* * *$} & \multicolumn{4}{|c|}{$* * *$} \\
\hline$r^{2}$ & \multicolumn{2}{|c|}{0.944} & \multicolumn{4}{|c|}{0.991} \\
\hline
\end{tabular}

${ }^{2}$ Limit of detection: Stem tissue $0.002 \mathrm{ng} \cdot \mathrm{g}$,', flowers $0.001 \mathrm{ng} \cdot \mathrm{g}$ '. *** Significant at $\mathrm{P} \geq 20.001$.

differences in response to postpacking treatment with Oasis Floral Preservative occurred, with the increase in postharvest life ranging from 1.4 times for 'Supreme' to 2.2 times in 'Pearl' compared to packed sprays held in deionized water (Table 1). The reduction in the postharvest life of 'Pearl', 'Supreme', 'Prince', and 'Blush' that were packed and placed in water only after unpacking was probably a response to stress that occurred during their storage. These cultivar responses to packing should be taken into account when selecting cultivars.

Dendrobium sprays appear to be more sensitive to low temperature than Phalaenopsis (Huang et al., 1988) or Cymbidium (Sheehan, 1954), as exposure to 10C for more than 4 days and to $7.5 \mathrm{C}$ for more than 2 days lead to $\mathrm{CI}$ in dendrobium.

Excessive water loss and poor vascular conductivity cause water stress, leading to a reduction in cut flower longevity (Halevy and Mayak, 1980). Water loss by 'Supreme' dendrobium flower sprays was very low compared to other flowers $(<2 \mathrm{~g}$ / day per spray) and the rate declined after harvest (Fig. 1). Similar results have been reported for another Dendrobiun cultivar (Ketsa and Boonrote, 1990) and other flowers (Mayak and Halevy, 1974). Dendrobium sprays treated continuously with Oasis Floral Preservative had higher water loss rates (Fig. 1) and longer vase lives than sprays treated with deionized water (Table 3). There was a relationship between the decline in water loss below $1 \mathrm{~g} /$ day per spray and the onset of flower shedding.

Sprays held in chloramphenicol, an inhibitor of $70 \mathrm{~S}$ protein synthesis, had $50 \%$ longer vase life than the deionized water control. Chloramphenicol inhibits bacterial growth but does not completely suppress yeast growth. As yeast has been associated with a loss in cut flower postharvest life (Zagory and Reid, 1986), this could provide an explanation for chloramphenicol's partial effectiveness in prolonging dendrobium longevity (Table 5). In control sprays, water stress was probably caused by bacterial growth in the solution that lead to blockage of the vascular system. The presence of bacterial contamination is supported by the observation that sprays held in deionized water had a slimy appearance and objectionable odor. Little slime was noticed on sprays held in Oasis Floral Preservative. The role of the preservative in prolonging vase life was possibly associated with the inhibition of microbial growth and the maintenance of vascular conductivity.

Sucrose has been the main ingredient of various pulsing solutions and has been found to be of great value in prolonging life, promoting opening, and improving the color and the size of petals in several flowers (Mayak et al., 1973), including dendrobiurn (Ketsa and Boonrote, 1990). However, pulsing with $5 \%$ sucrose for $24 \mathrm{~h}$ did not affect dendrobium flower vase life in our study (Table 3). Pulsing dendrobium sprays for $24 \mathrm{~h}$ with a $5 \%$ sucrose solution (Table 3 ) with a water uptake rate of $<2$ g/day per spray (data not shown) would have lead to a maximum uptake of $100 \mathrm{mg} / \mathrm{spray}$ and that may have been insufficient to have a significant effect on postharvest life. Sucrose at concentrations from $2 \%$ to $10 \%$ reduced dendrobium postharvest life by $50 \%$ (Ketsa and Boonrote, 1990), while $4 \%$ glucose increased postharvest life by $20 \%$ when flowers were continuously held in these solutions. Reduced postharvest life was found with Oncidium orchids held in $2 \%$ (w/v) sucrose (Yong and Ong, 1979) and is probably associated with microbial growth, as were the results of Ketsa and Boonrote (1990) where germicide was not present.

Ethylene has been implicated in Vanda petal fading (Akamine, 1963; Burg and Dijkman, 1967) and in dendrobium flower senescence (Nair and Fong, 1987; Nair and Tung, 1983). Silver ions failed to give a marked improvement in Dendrobium orchid postharvest life (Nowak and Vacharotayan, 1980) even though silver ion applied as silver thiosulfate reached every part of the spray (Table 7). The failure of silver to increase postharvest life (Tables 3 and 6) was possibly due to either insufficient silver ion reaching the flower buds or the lower sensitivity of Dendrobium flowers to ethylene (Gob et al., 1985) when compared to other orchids such as Vanda (Akamine, 1963; Burg an Dijkman, 1967) and Phalaenopsis (Huang et al., 1988).

In summary, the variability in postharvest life of dendrobium flowers was caused by seasonal variation and cultivar differences. The shedding of flowers apparently was caused by water stress. Microbial growth in the holding solution and on the flower stem appears to be the main cause of vascular blockage, subsequent water stress, and reduced postharvest life. Submerging dendrobium sprays for 5 min in tap water before packing could be recommended to remove any field heat, although it had little apparent effect on the postharvest life of the sprays. Sprays should be held packed for less than 4 days and should not be held for more than 4 days at 10C. There was little response to holding the sprays in most preservative solutions before packing, while the commercial preservative Oasis Floral Preservative gave the greatest extension of vase life when used both before and after packing.

\section{Literature Cited}

Akamine, E.K. 1963. Ethylene production in fading Vanda orchid blossoms. Science 140:1217-1218.

Burg, S.P. and M.J. Dijkman. 1967. Ethylene and auxin participation in pollen reduced fading of Vanda orchid blossoms. Plant Physiol. 42:1648-1650.

Goh, C.J., A.H. Halevy, R. Engel, and A.M. Kofranek. 1985. Ethylene evolution and sensitivity in cut orchid flowers. Scientia Hort. 26:57-67.

Halevy, A.H. and S. Mayak. 1980. Senescence and postharvest physiology of cut flowers. Part 1. Hort Rev. 1:204-236.

Huang, C. C., S.C. Lin, and Y.T. Wing. 1988. Study on the improvement of postharvested Phalaenopsis quality. Proc. Symp. Imp. Orchid Production, Taitang, Taiwan District Agr. Improvement Sta. p. 33-40.

Kamemoto, H. 1987. Genome breeding in Dendrobium orchids, p. 182-188. In: C.H. Huang (cd.). The breeding of horticultural crops. Food \& Agr. Tech. Ctr., Taipei, Taiwan.

Ketsa, S. and A. Boonrote. 1990. Holding solutions for maximizing . bud opening and vase life of Dendrobium 'Youppadeewan' flowers. J. Hort. Sci. 65:41-47.

Larsen, F.E. and R.W. Cromarty. 1967. Microorganisms inhibition by 
8-hydroxyquinoline citrate as related to cut flower senescence. Proc. Amer. Soc. Hort. Sci. 90:546-549.

Marousky, F.J. 1971. Inhibition of vascular blockage and increase moisture retention in cut roses induced by $\mathrm{pH}, 8$-hydroxyquinoline citrate, and sucrose. J. Amer. Soc. Hort. Sci. 96:38-41.

Mayak, S. and A.H. Halevy. 1974. The action of kinetin in improving the water balance and delaying senescence processes of cut rose flowers. Phvsiol. Plant. 32:330-336.

Mayak, S., B: Bravdo, A. Gvilli, and A.H. Halevy. 1973. Improvement of opening of cut gladioli flowers by pretreatment with high sugar concentrations. Scientia Hort. 1:357-365.

Mayak, S., E.A. Garibaldi, and A.M. Kofranek. 1977. carnation flower longevity: Microbial populations as related to silver nitrate stem impregnation. J. Amer. Soc. Hort. Sci. 102:637-639.

Nair, H. and T.H. Fong. 1987. Ethylene production and 1-aminocyclopropane-1-carboxylic acid levels in detached orchid flowers of Dendrobium 'Pompadour'. Scientia Hort. 32:145-151.

Nair, H. and H.F. Tung. 1983. Some postharvest studies on detached flowers of Dendrobium pompadour. Malay Orchid Rev. 17:22-30.

Nolte, F. 1985. Longevity of cut Dendrobium from Thailand. Deutscher Gartenbau 39:2178.

Nowak, J. and S. Vacharotayan. 1980. Evaluation of different chemical treatments for keeping-quality and vase-life prolongation of some orchid cultivars. Prace Instytutu Sadowrictwa I Kwiaciarstwa Series B 5:83-93.
Poole, R. T., C.A. Conover, and R.H. Stamps. 1984. Vase life of leatherleaf fern harvested at various times of the year and at various frond ages. Proc. Fla. State Hort. Soc. 97:266-269.

Put, H.M.C. and L. Jansen. 1989. The effects on the vase life of cut Rosa cultivar 'Sonia' of bacteria added to the vase water. Scientia Hort. 39:167-179.

Sheehan, T.J. 1954. Orchid flower storage. Amer. Orchid Soc. Bul. 23:579-584.

Sheehan, T.J. 1983. Recent advances in botany, propagation and physiology of orchids. Hort. Rev. 5:279-315.

Stamps, R. H., T.A. Nell, and D.J. Cantliffe. 1989. Production temperature affects leatherleaf fern postharvest desiccation. HortScience 24:325-327.

van Doom, W. G., K. Schurer, and Y. de Witte. 1989. Role of endogenous bacteria in vascular blockage of cut rose flower. J. Plant Physiol. 134:375-381.

Witte, Y. de and W.G. van Doom. 1988. Identification of bacteria in the vase water of roses, and the effect of the isolated strains on water uptake. Scientia Hort. 35 :285-291.

Yong, H.C. and H.T. Ong. 1979. Effects of chemicals applied to cut stalks on the shelf life of Oncidium goldiana flowers. Orchid Rev. 87(1035):292-295.

Zagory, D. and M.S. Reid. 1986. Role of vase solution microorganisms in the life of cut flowers. J. Amer. Soc. Hort. Sci. 111:154158. 